\title{
CD3 Hyporesponsiveness and In Vitro Apoptosis Are Features of T Cells from Both Malignant and Nonmalignant Secondary Lymphoid Organs
}

\author{
Samir Agrawal, ${ }^{* \mid \pi}$ Jeanine Marquet, ${ }^{\star \uparrow}$ Marie-Hélène Delfau-Larue, ${ }^{\star \star \star}$ Christiane Copie-Bergman, ${ }^{\ddagger}$ Hélène Jouault, \\ Felix Reyes, "Armand Bensussan," and Jean Pierre Farcet ${ }^{\star \Uparrow}$ \\ *Department of Immunology, ${ }^{\ddagger}$ Department of Histopathology, ${ }^{\S}$ Department of Laboratory Hematology, and $\|_{\text {Department of Clinical }}$ \\ Hematology, and INSERM Research Units ${ }^{\top} U 448$ and ${ }^{* *} U 474$, Henri Mondor Hospital, Créteil, France
}

\begin{abstract}
There is a dogma in tumor immunology that tumor-infiltrating lymphocytes (TIL) are defective based on their lack of antitumoral efficacy in vivo and on impaired response to in vitro functional tests. However, TIL have been compared usually with peripheral blood $\mathrm{T}$ lymphocytes, raising doubts on the conclusions drawn. Therefore, we compared TIL from B cell non-Hodgkin's lymphomas (NHL) with T cells from nonmalignant secondary lymphoid organs. NHL-TIL were unresponsive to activation by immobilized anti-CD3 mAb, although bypassing $\mathrm{T}$ cell receptor (TCR)/CD3 signaling led to proliferation. The poor proliferative responses of NHL-TIL could not be explained by quantitative defects in TCR $\zeta$ expression. NHLTIL underwent marked spontaneous apoptosis in vitro with loss of $\sim 50 \%$ of cells after $24 \mathrm{~h}$ of culture. This was associated with downregulation of the antiapoptotic Bcl- $\mathrm{x}_{\mathrm{L}}$ and Bcl-2 proteins, whereas viable NHL-TIL maintained their expression. IL-2, anti-CD3/IL-2, and manipulation of the Fas/Fas-ligand death pathway had no effect on NHL-TIL survival. Apoptosis was not due to increased cell cycling, as NHL-TIL were quiescent, nonproliferating cells. $\mathrm{T}$ cells from inflammatory, nonmalignant tissues gave similar functional results to NHL-TIL, suggesting the existence of factors common to the microenvironment of these diverse pathologies. Thus, the quiescent, anergic phenotype of NHL-TIL cannot be attributed solely to tumor factors, but rather is a feature of $\mathrm{T}$ cells from chronic inflammatory lesions. (J. Clin. Invest. 1998. 102:1715-1723.) Key words: tumor infiltrating lymphocytes • non-Hodgkin's lymphoma • inflammatory tissue $\bullet$ Bcl- 2 • anergy
\end{abstract}

\section{Introduction}

A lymphocytic infiltrate is associated with almost all solid cancers and yet the presence of tumor-infiltrating T lymphocytes (TIL) ${ }^{1}$ does not lead to an effective immune response in the majority of cases. The nonfunctionality of TIL has been attributed to various mechanisms, including a lack, or absence, of the costimulatory molecules CD80 and CD86 on tumor cells leading

Address correspondence to Dr. S. Agrawal, INSERM U448, Faculté de Médecine, 8, rue du Gl Sarrail, 94010 Créteil, France. Phone: 33-149-81-35-15; FAX: 33-1-49-81-36-05; E-mail: medsci@hol.fr

Received for publication 21 April 1998 and accepted in revised form 26 August 1998.

J. Clin. Invest.

(C) The American Society for Clinical Investigation, Inc. 0021-9738/98/11/1715/09 \$2.00

Volume 102, Number 9, November 1998, 1715-1723

http://www.jci.org to anergy (1-3), and the production of suppressive factors by the tumor $(4,5)$.

Many studies have documented poor proliferative responses of TIL from different types of cancers to mitogenic stimuli (6-10). In B cell non-Hodgkin's lymphoma (NHL), TIL have been shown to proliferate poorly to IL-2, immobilized anti-CD3 $\mathrm{mAb}$, and to a combination of the two, although occasionally NHL-TIL proliferate normally $(11,12)$. Most studies have used peripheral blood T lymphocytes (PBL-T) as controls for TIL. However, data from T cells derived from tissues not involved by a malignant process, such as the lamina propria (13), synovium (14), and intestine (15), show a similar pattern of impaired proliferation.

A variety of alterations in signal transduction molecules has been reported in both mouse tumor models $(16,17)$ and in TIL from human cancers $(9,18)$. In view of the poor proliferative responses of TIL to T cell receptor (TCR)/CD3 stimulation, much attention has focused on the TCR $\zeta$ component of the complex (19). Decreased levels of TCR $\zeta$ have been found in TIL from human renal cell (9) and colorectal (20) carcinoma and in splenic $\mathrm{T}$ cells from tumor bearing mice (16). However, some workers have suggested that reduced TCR $\zeta$ levels may be artifactual and due to digestion by granulocytic proteases $(17,19,21)$. In NHL-TIL, Wang et al. have reported normal levels of TCR $\zeta, \mathrm{CD} 3 \epsilon$, and of the protein tyrosine kinases, p56 lck , p59 fyn , and ZAP-70 (22), although they did find qualitative changes in $\mathrm{p} 56^{\text {lck }}$. Once again, however, few studies have used tissue T cells as controls for TIL and where this has been done tonsillar tissue was found to express the same levels of TCR $\zeta$ as lymphomas (22). These findings, combined with the data from proliferation assays in vitro, suggest that tissue $\mathrm{T}$ cells are more appropriate controls than PBL-T for assessing the functionality of NHL-TIL.

In this study, we have directly compared NHL-TIL with T cells from inflammatory, nonmalignant secondary lymphoid organs (referred to as reactive T cells) and PBL-T. NHL-TIL and reactive $\mathrm{T}$ cells were both found to show hyporesponsiveness to TCR/CD3 activation but express similar levels of $\mathrm{TCR} \zeta$ as PBL-T. One factor in the poor proliferation of TIL and reactive $T$ cells may be an increased propensity to undergo apoptosis in vitro as compared with PBL-T. Indeed, Salmon et al. have shown a marked susceptibility of synovial $\mathrm{T}$ cells in rheumatoid arthritis to undergo apoptosis in vitro (23). We found that NHL-TIL and reactive $\mathrm{T}$ cells were remarkably

1. Abbreviations used in this paper: AV, annexin V; FasL, Fas-ligand; MFI, mean fluorescence intensity; NHL, non-Hodgkin's lymphoma; PBL-T, peripheral blood T lymphocytes; PI, propidium iodide; reactive $\mathrm{T}$ cells, $\mathrm{T}$ cells from chronic inflammatory, nonmalignant secondary lymphoid organs; TCR, T cell receptor; TIL, tumor-infiltrating T lymphocytes. 
similar in terms of their poor in vitro survival and that the Fas/ Fas-ligand (FasL) pathway was not involved in this phenomenon. In addition, our results show that the CD3 hyporesponsiveness of these cell populations is not principally attributable to their increased degree of spontaneous apoptosis. Thus, $\mathrm{T}$ cells from different chronic inflammatory lesions are functionally similar and the phenotype of NHL-TIL cannot be attributed solely to tumor-specific factors.

\section{Methods}

Samples and cell preparation. 13 cases of NHL were studied, consisting of 10 lymph node biopsies ( 9 follicular lymphomas and 1 chronic lymphocytic leukemia) and 3 splenectomy samples (splenic lymphoma with villous lymphocytes, mantle cell lymphoma, and lymphoplasmocytic lymphoma). Control tissues were whole tonsils from children undergoing tonsillectomy for recurrent infections, lymph node biopsies showing benign follicular hyperplasia, and splenectomies performed for autoimmune hemolytic anemia and trauma. All biopsies were received fresh, in a sterile container without any medium, and were processed immediately. Cell suspensions were obtained either by repeated perfusion with complete medium using a 19G needle or by mincing over a wire mesh. The cell suspensions were then filtered through a $100-\mu \mathrm{m}$ filter to remove aggregates and viability was assessed by trypan blue exclusion. Peripheral blood mononuclear cells were isolated by Ficoll-Paque centrifugation of peripheral blood from patients with NHL and healthy donors. All cells were cryopreserved in $10 \%$ DMSO with $20 \%$ FCS and stored in liquid nitrogen until testing.

Highly purified $\mathrm{T}$ cell populations were obtained by negative selection using a cocktail of hapten-modified Abs (CD11b, CD16, CD19, CD36, and CD56) followed by antihapten magnetic microbeads (pan-T cell isolation kit; Miltenyi Biotec, Bergisch Gladbach, Germany). For the purification of some tissue samples, anti-CD19 magnetic microbeads were also added to take account of the greater proportion of B cells. All purified T cell populations were CD19-, $\mathrm{CD}_{56}{ }^{-}$, and $>96 \%$ (and most were $>98 \%$ ) $\mathrm{CD}^{+}$. Cell cultures were performed with complete medium: RPMI 1640 supplemented with $10 \%$ FCS, $2 \mathrm{mM}$ L-glutamine, $100 \mathrm{U} / \mathrm{ml}$ penicillin, $100 \mu \mathrm{g} / \mathrm{ml}$ streptomycin, and $1 \mathrm{mM}$ sodium pyruvate.

In this paper, $\mathrm{T}$ cells from NHL biopsies will be referred to as NHL-TIL; $\mathrm{T}$ cells from benign lesions as reactive $\mathrm{T}$ cells; and $\mathrm{T}$ cells from peripheral blood as PBL-T.

Surface and intracellular immunofluorescence analysis. The following FITC-conjugated $\mathrm{mAbs}$ were used for detection of surface molecules: CD4 (S3.5), CD8 (3B5), CD25 (CD25-3G10), CD45RA (MEM56), CD45RO (UCHL1), HLA-DR (TU 36) (all from Caltag Laboratories, Burlingame, CA), CD62L (Dreg 56; Immunotech, Marseille, France), and CD86 (FUN-1; PharMingen, San Diego, CA). Other directly conjugated mAbs used were anti-CD3-TRICOLOR (S4.1), CD19-TRICOLOR (SJ25-C1; Caltag), CD45RO-PE (Immunotech), and CD86-PE (FUN-1; PharMingen). CH11 (Immunotech), an IgM anti-Fas (CD95) mAb, was used unconjugated and revealed by a FITC-labeled goat anti-mouse Ig (Caltag). Pretitrated quantities of $\mathrm{mAbs}$ were added for $15 \mathrm{~min}$ at $4^{\circ} \mathrm{C}$ and cells were then washed in staining buffer (PBS, $5 \%$ FCS, and $0.02 \%$ sodium azide) and fixed in $1 \%$ paraformaldehyde. All tests were analyzed on a EPICS XL flow cytometer (Coulter Corp., Hialeah, FL). Isotype control Abs were used to establish the PMT settings and singly stained samples allowed compensation for double- and triple-color immunofluorescence tests.

For intracellular labeling, cells were fixed in PBS 1\% paraformaldehyde for $20 \mathrm{~min}$ at $4^{\circ} \mathrm{C}$, washed, and then permeabilized with staining buffer containing $0.1 \%$ saponin and the specific $\mathrm{Ab}$ for $20 \mathrm{~min}$ at $4^{\circ} \mathrm{C}$. Cells were washed in staining buffer and, if required, the secondary $\mathrm{Ab}$ was added, also diluted in staining buffer containing $0.1 \%$ saponin. Anti-human Bcl-2 mAb (124; DAKO, Glostrup, Denmark) was FITC-conjugated and compared with an isotype control. Bcl- $\mathrm{x}_{\mathrm{L}}$ was detected by a polyclonal anti-Bcl- $\mathrm{x}_{\mathrm{L} / \mathrm{S}} \mathrm{Ab}^{2}$ (Santa Cruz Biotechnologies, Santa Cruz, CA) and a FITC-labeled goat anti-rabbit Ig (Caltag) as the secondary Ab. Anti-TCR $\zeta$ (TIA-2; Coulter) Ab was detected with a PE-labeled goat anti-mouse Ig (Caltag). Staining with the secondary $\mathrm{Ab}$ alone was used as the negative control for $\mathrm{TCR} \zeta$ and $\mathrm{Bcl}-\mathrm{x}_{\mathrm{L} / \mathrm{S}}$. We confirmed the positivity of the anti-Bcl-2 and anti-Bcl- $x_{L / S}$ Abs by staining the $t(14 ; 18)$ containing lymphoma cell line, RL, and PHA blasts, respectively (data not shown).

Cell survival, apoptosis, and cell cycle analysis. All experiments were performed on pure $\mathrm{T}$ cell populations isolated from rapidly thawed cryopreserved samples. Viability was assessed by trypan blue exclusion and $10^{5}$ trypan blue negative cells per well were planted in 96-well round bottom plates (Costar) in $0.2 \mathrm{ml}$ of complete medium. Apoptosis was detected by the appearance of phosphatidylserine residues at the cell surface by labeling with annexin V (AV) (Annexin V-FITC kit; Bender MedSystems, Vienna, Austria) for $10 \mathrm{~min}$ at room temperature, in the dark. Propidium iodide (PI) $(20 \mu \mathrm{g} / \mathrm{ml})$ was added to exclude necrotic cells from analysis. The population of live lymphocytes was gated on using the morphological criteria of forward and side scatter. For cell cycle analysis, cells were washed in PBS and then fixed and permeabilized with $1 \mathrm{ml}$ of ice-cold $70 \%$ ethanol for $1 \mathrm{~h}$ at $4^{\circ} \mathrm{C}$. After centrifugation and washing, $50 \mu \mathrm{g} / \mathrm{ml}$ PI (Sigma Chemical Co., St. Louis, MO) and $75 \mu \mathrm{g} / \mathrm{ml}$ RNase A (Sigma) were added for 45 $\mathrm{min}$ at $37^{\circ} \mathrm{C}$. Samples were analyzed immediately on an EPICS XL.

The time course of cell survival was evaluated by daily harvesting of independent wells and assessing viability by trypan blue exclusion (all measurements made in duplicate) and apoptosis and cell cycle analysis as above. The effect of various agents on cell survival was tested by addition at the start of cultures of: IL-2 $(50 \mathrm{U} / \mathrm{ml}$; Eurocetus, Amsterdam, The Netherlands); immobilized anti-CD3 mAb (CD3ana3, see below); immobilized anti-CD3 plus IL-2; $10 \mu \mathrm{g} / \mathrm{ml}$ of the anti-Fas (CD95) blocking Ab, ZB4 (MBL, Nagoya, Japan); or an isotype control. Induction of apoptosis by activation of Fas (CD95) was performed as previously described (24) with minor modifications. In brief, cells were incubated with the agonistic anti-Fas Ab, APO-1 (APO-1.3; Alexis, San Diego, CA) for $1 \mathrm{~h}$ at $37^{\circ} \mathrm{C}$, then cross-linked with a rat anti-mouse $\mathrm{Ig}$ $(10 \mu \mathrm{g} / \mathrm{ml}$; Caltag) and examined for AV staining. PHA blasts (24) were used as positive controls.

$T$ cell proliferation assays. $5 \times 10^{4} \mathrm{~T}$ cells per well were planted in 96-well round-bottomed plates in a final volume of $0.2 \mathrm{ml}$ of complete medium. Cells were cultured in triplicate wells with medium alone or with the following stimuli: anti-CD3 mAb (CD3ana3, produced in our laboratory), which was used in cross-linking conditions, i.e., preimmobilized onto wells at a 1:5,000 dilution of ascites; $10 \mathrm{ng} / \mathrm{ml}$ PMA (Sigma); $10^{-6} \mathrm{M}$ ionomycin (Sigma); IL-2 $(50 \mathrm{U} / \mathrm{ml})$; and $1 \mu \mathrm{g} / \mathrm{ml}$ anti-CD28 (CD28.2; kindly donated by D. Olive, Marseille, France). Combinations of these stimuli were also used, as detailed in the text. Cultures were incubated in a humidified incubator with $5 \% \mathrm{CO}_{2}$ in air at $37^{\circ} \mathrm{C}$ for $96 \mathrm{~h}$. During the last $8 \mathrm{~h}$ of the culture, $1 \mu \mathrm{Ci}$ of $\left[{ }^{3} \mathrm{H}\right]$ thymidine (ICN, Irvine, CA) was added per well and then cells were harvested on a Packard Harvester (Packard, Meridian, CT). Incorporation of radioactivity was determined using a microplate scintillation counter (Top Count; Packard).

Statistical analysis. All data were analyzed using the nonparametric Wilcoxon test.

\section{Results}

NHL-TIL and reactive T cells express a predominantly activated, memory immunophenotype. First, we established whether the

2. No Bcl- $x_{L}$-specific $m A b$ was commercially available at the time of this study. In all tissues and cell lines studied, Bcl- $x_{L}$ is dominant (mRNA 100 times greater than all other isoforms of Bcl-x) and Bcl- $\mathrm{x}_{\mathrm{S}}$ has not been detected in mature human lymphocytes $(34,71)$. Thus, it is possible to use an anti-Bcl- $\mathrm{x}_{\mathrm{L} / \mathrm{S}} \mathrm{Ab}$ to specifically detect the $\mathrm{Bcl}-\mathrm{x}_{\mathrm{L}}$ protein in mature human $\mathrm{T}$ cells by flow cytometry. 
Table I. Immunophenotyping of NHL-TIL

\begin{tabular}{|c|c|c|c|c|c|c|c|c|c|c|}
\hline & \multirow[t]{2}{*}{ CD3+ } & \multirow[b]{2}{*}{ CD62L } & \multicolumn{7}{|c|}{ \%OF CD3+ T CELLS POSITIVE FOR: } & \multirow{2}{*}{$\begin{array}{l}\text { RATIO } \\
\text { CD4:CD8 }\end{array}$} \\
\hline & & & CD45RA & CD45RO & HLA-DR & CD25 & CD86 & CD4 & CD8 & \\
\hline FL1 & 22 & 12 & 17 & 81 & 100 & 36 & 75 & 91 & 9 & 10.1 \\
\hline FL2 & 49 & 11 & 19 & 76 & 100 & 21 & 16 & 78 & 22 & 3.5 \\
\hline FL3 & 60 & 16 & 5 & 95 & 99 & 19 & 79 & 81 & 19 & 4.2 \\
\hline FL4 & 14 & 18 & 28 & 79 & 100 & 18 & 60 & 44 & 56 & 0.8 \\
\hline FL5 & - & 18 & 17 & 89 & 100 & 15 & 4 & 40 & 57 & 0.7 \\
\hline FL6 & - & 18 & 31 & 79 & 56 & 5 & 5 & 77 & 21 & 3.7 \\
\hline FL7 & 54 & 30 & 15 & 95 & 86 & 15 & 8 & 60 & 40 & 1.5 \\
\hline CLL & 12 & 64 & 20 & 93 & 94 & 8 & 14 & 63 & 37 & 1.7 \\
\hline MCL & 5 & 17 & 9 & 92 & 72 & 21 & 23 & 60 & 40 & 1.5 \\
\hline SLVL & 5 & 20 & 50 & 81 & 100 & 30 & 46 & 44 & 56 & 0.8 \\
\hline MEAN & 28 & 22 & 21 & 86 & 91 & 19 & 33 & 64 & 36 & 2.8 \\
\hline MEDIAN & 18 & 18 & 17 & 89 & 100 & 19 & 20 & 62 & 39 & 2.6 \\
\hline RANGE & $5-60$ & $11-64$ & $5-50$ & $76-95$ & $72-100$ & $8-36$ & 4-79 & $40-91$ & $9-57$ & $0.7-10.1$ \\
\hline
\end{tabular}
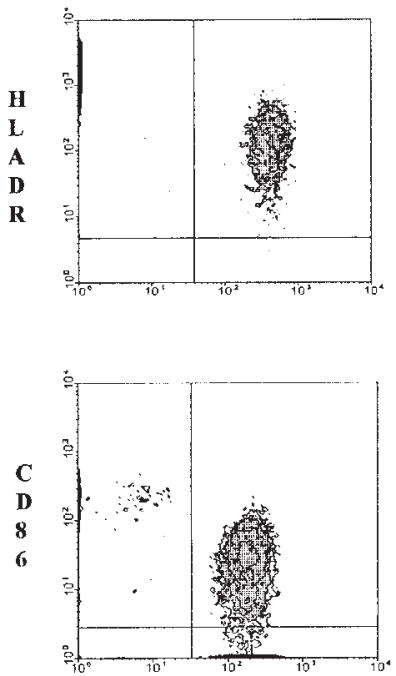

CD 3

Percentages were determined by flow cytometry of mononuclear cell or purified T cell suspensions. Double staining confirmed the presence of a pop-

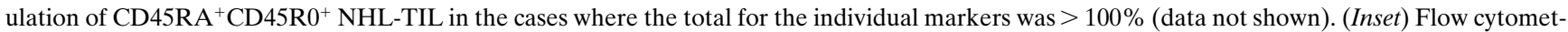
ric images of HLA-DR and CD86 expression on $\mathrm{CD}^{+}$cells from FL3. FL, Follicular lymphoma; $C L L$, chronic lymphocytic leukemia; MCL, mantle cell lymphoma; $S L V L$, splenic lymphoma with villous lymphocytes.

distributions of $\mathrm{T}$ cell subsets in reactive $\mathrm{T}$ cells and NHL-TIL were comparable by immunophenotyping the mononuclear cell suspensions of NHL and control tissues using double and triple immunofluorescence flow cytometry. Table I shows that the majority of NHL-TIL expressed the memory/effector marker CD45RO along with the activation marker HLA-DR. The median CD4/CD8 ratio was 2.6. It is of note that the median HLA-DR positivity was $100 \%$ (Table I and inset), whereas that of CD25 was only $19 \%$. CD86 (B7.2) is well char- acterized as a costimulatory molecule on antigen presenting cells; however, its role on T cells remains unclear. CD86 expression is very low on resting PBL-T but is upregulated during $\mathrm{T}$ cell activation $(25,26)$, being maximal at $24-48 \mathrm{~h}$ and then decreasing (i.e., similar to CD25). In this context, it is interesting to note the elevated expression of CD86 in some NHL-TIL (Table I and inset). The same profile of markers was shown by control reactive $\mathrm{T}$ cells (Table II), with a median $\mathrm{CD} 4 / \mathrm{CD} 8$ ratio of 2.7 , although the range of activation marker

Table II. Immunophenotyping of Reactive T Cells

\begin{tabular}{|c|c|c|c|c|c|c|c|c|c|c|}
\hline & \multirow[b]{2}{*}{$\mathrm{CD}^{+}$} & \multicolumn{8}{|c|}{$\%$ of $\mathrm{CD}^{+}{ }^{+} \mathrm{T}$ cells positive for: } & \multirow{2}{*}{$\begin{array}{l}\text { Ratio } \\
\text { CD4/CD8 }\end{array}$} \\
\hline & & CD62L & CD45RA & CD45RO & HLA-DR & $\mathrm{CD} 25$ & CD86 & $\mathrm{CD} 4$ & $\mathrm{CD} 8$ & \\
\hline LN 1 & 70 & 37 & 73 & 24 & 21 & 9 & 9 & 69 & 31 & 2.2 \\
\hline $\mathrm{LN} 2$ & 61 & 10 & 32 & 64 & 10 & 9 & 6 & 80 & 20 & 4.0 \\
\hline SPL 1 & 73 & 2 & 16 & 75 & 100 & 1 & ND & 64 & 36 & 1.8 \\
\hline SPL 2 & 55 & 5 & 37 & 64 & 100 & 5 & 6 & 55 & 45 & 1.2 \\
\hline SPL 3 & 50 & 5 & 18 & 82 & 12 & 2 & 13 & 75 & 25 & 3.0 \\
\hline SPL 4 & 60 & 5 & 28 & 61 & 19 & 3 & 4 & 57 & 43 & 1.3 \\
\hline TON 1 & 21 & 5 & 17 & 81 & 90 & 5 & 22 & 74 & 26 & 2.9 \\
\hline TON 2 & 20 & 6 & 17 & 73 & 21 & 7 & 15 & 55 & 45 & 1.2 \\
\hline TON 3 & 20 & 6 & 20 & 70 & 100 & 5 & 30 & 73 & 27 & 2.7 \\
\hline TON 4 & 24 & 2 & 9 & 80 & 90 & 4 & 21 & 76 & 24 & 3.2 \\
\hline TON 5 & - & 20 & 36 & 65 & 28 & 8 & 0 & 69 & 23 & 3.0 \\
\hline Mean & 45 & 9 & 28 & 67 & 54 & 5 & 13 & 68 & 31 & 2.4 \\
\hline Median & 52.5 & 5 & 20 & 70 & 28 & 5 & 11 & 69 & 27 & 2.7 \\
\hline Range & $20-73$ & $2-37$ & $9-73$ & $24-82$ & $12-100$ & $1-9$ & $0-30$ & $55-80$ & $20-45$ & $1.2-4.0$ \\
\hline
\end{tabular}

Percentages were determined by flow cytometry of mononuclear cell or purified T cell suspensions. TON, Tonsil; $L N$, lymph node; $S P L$, spleen; $N D$, not done. 


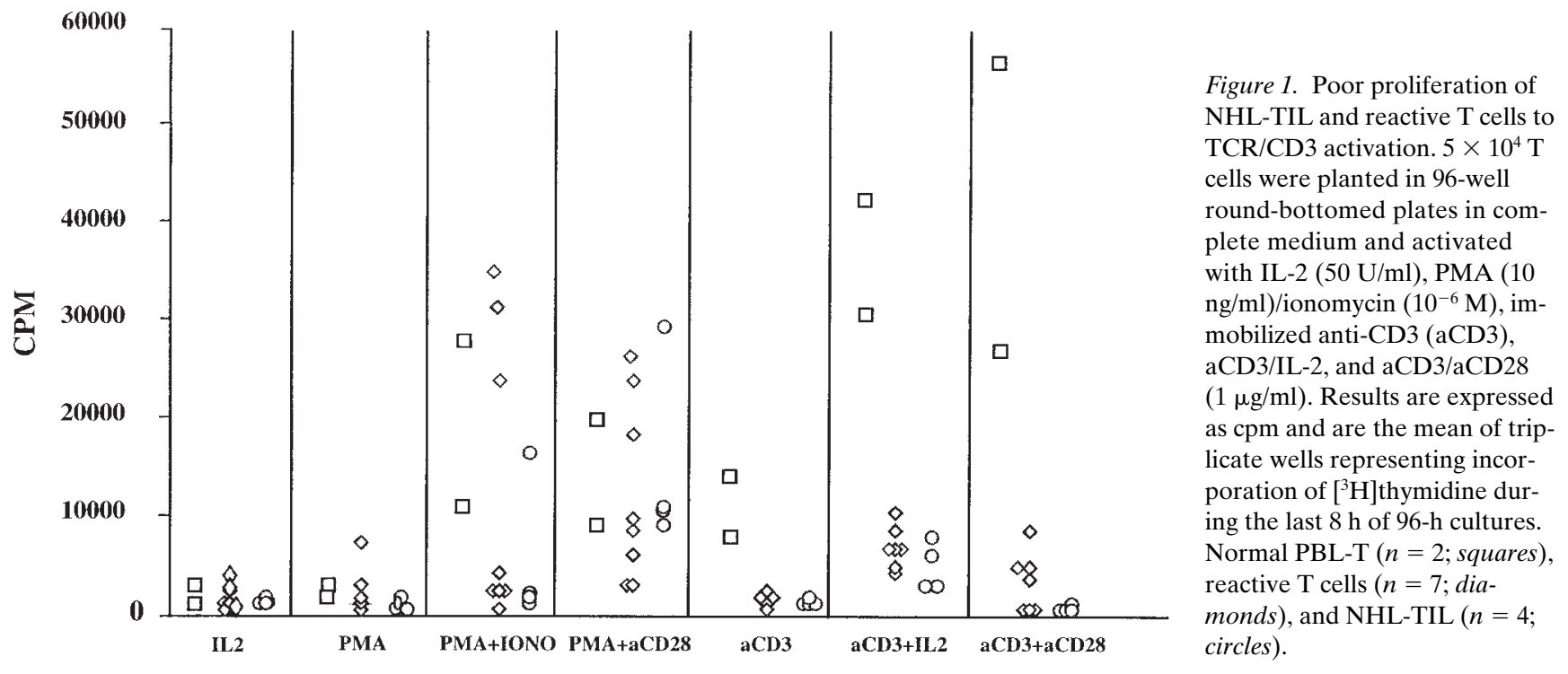

expression was broader. Of the activation markers, CD25 $(P=$ $0.001)$, but not HLA-DR $(P=0.06)$ or CD86 $(P=0.15)$, was significantly higher in NHL-TIL. Overall, reactive T cells and NHL-TIL had a similar CD4/CD8 ratio and predominantly expressed an activated, memory phenotype which is clearly distinct from that of PBL-T (27). The immunophenotype of PBL-T from NHL patients did not differ from that of normal PBL-T (data not shown).

Impaired TCR/CD3 activation in NHL-TIL and reactive $T$ cells as compared with PBL-T cannot be attributed to decreased TCR $\zeta$ expression. Using a variety of activation stimuli (IL-2, PMA, PMA/ionomycin, and PMA/anti-CD28), we found that NHL-TIL and reactive $\mathrm{T}$ cells showed a heterogeneous pattern of responses, with samples showing a lower, similar, or greater level of proliferation than normal PBL-T (Fig. 1). However, the most striking observation was the nonproliferation of all NHL-TIL and reactive T cell samples with immobilized anti-CD3 (Fig. 1). The combination of anti-CD3/CD28 was ineffective in NHL-TIL and anti-CD3/IL-2 only produced weak proliferation in NHL-TIL and reactive T cells, whereas both combinations were strongly synergistic in PBL-T. All conditions involving anti-CD3 in NHL-TIL and reactive $\mathrm{T}$ cells gave statistically significant differences as compared with PBL-T (anti-CD3, $P=0.0379$; anti-CD3/IL-2 and anti-CD3/ anti-CD28, $P=0.0382)$. In NHL-TIL, the best proliferative response was always seen with PMA/anti-CD28, indicating that these cells can be activated by bypassing the TCR/CD3 signaling pathway and that the CD28 pathway is functional. These results cannot be explained simply by the subset differences between NHL-TIL and PBL-T, with a marked CD45RO ${ }^{+}$predominance among NHL-TIL (mean CD45RO ${ }^{+}=86 \%$, see Table I), as activation of accessory cell-depleted PBL-T with immobilized anti-CD3 $\mathrm{mAb}$ leads to proliferation of the $\mathrm{CD}_{45 \mathrm{RO}^{+}}$and not the CD45RA ${ }^{+}$subset $(28,29)$.

To further investigate the impaired signaling via the TCR/ CD3 complex, the expression of TCR $\zeta$ was studied. At day 0 , all the populations tested had $>90 \%$ of $\mathrm{T}$ cells positive for $\mathrm{TCR} \zeta$, with a similar mean fluorescence intensity (MFI) (Fig. 2 , dotted lines). After $24 \mathrm{~h}$ of culture in complete medium, gated cells in all populations showed spontaneous upregulation of TCR $\zeta$ expression (Fig. 2, solid lines). Notably, NHL-
TIL did not show decreased TCR $\zeta$ expression as compared with reactive $\mathrm{T}$ cells or normal PBL-T.

Increased spontaneous apoptosis and poor survival kinetics of NHL-TIL and reactive T cells as compared with PBL-T is not due to increased cell cycling. We studied the survival kinetics of these three populations cultured in complete medium without any stimuli. AV binding was used to detect the loss of asymmetry of the cell membrane and the appearance of phosphatidylserine residues at the cell surface, which is a relatively early

PBL.T

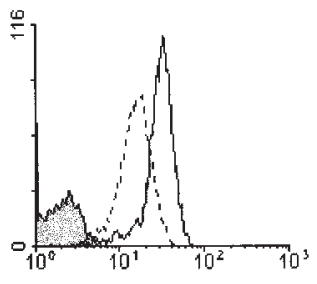

A

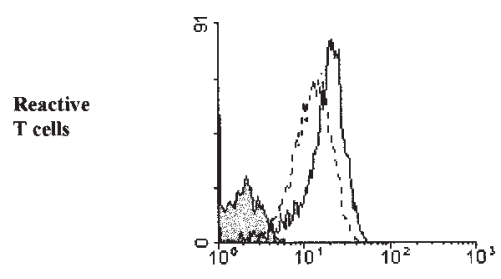

B

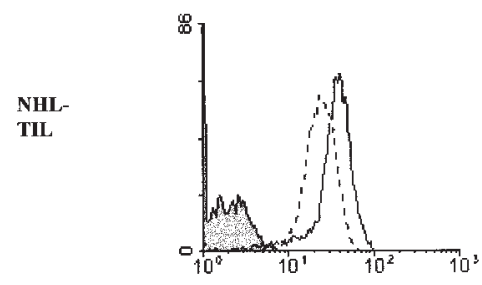

C

TCR $\zeta$
Figure 2. Similar expression and modulation of TCR $\zeta$ by NHLTIL and reactive T cells as compared with PBL-T. Intracellular staining for TCR $\zeta$ was performed immediately after $\mathrm{T}$ cell purification (dotted lines) and after $24 \mathrm{~h}$ in culture in complete medium, without lines). Controls are represented by filled curves. additional stimuli (solid 
A PBL-T

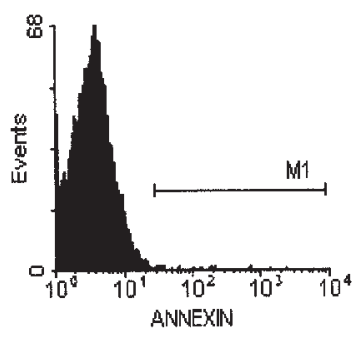

C NHL-TIL

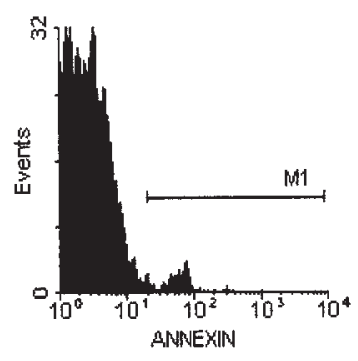

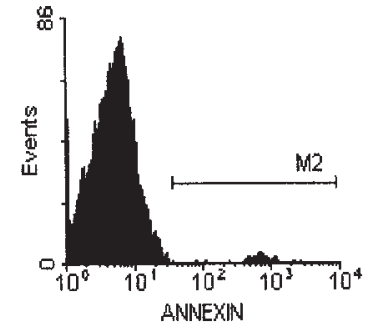

\section{B Reactive-T cells}
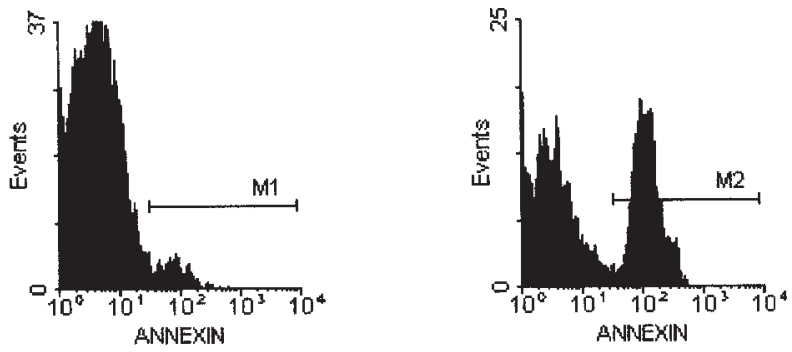

D

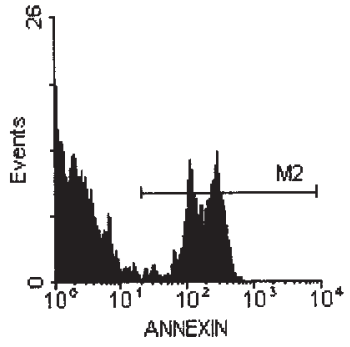

Figure 3. Poor viability of NHL-TIL and reactive T cells in culture. T cells were cultured in 96-well round-bottomed plates at $10^{5}$ trypan bluenegative cells/well. Apoptosis was measured as the percentage of $\mathrm{AV}^{+}$cells immediately after $\mathrm{T}$ cell purification and after $24 \mathrm{~h}$ in complete medium. Forward and side scatter characteristics were used to gate the population of live T cells. Representative examples of AV staining at the initiation of cultures (left-hand panels) and after $24 \mathrm{~h}$ (right-hand panels) are shown for $(A)$ normal PBL-T: M1 $=1.5 \%, \mathrm{M} 2=3 \% ;(B)$ reactive $\mathrm{T}$ cells: $\mathrm{M} 1=3.3 \%, \mathrm{M} 2=21.2 \% ;(C)$ NHL-TIL: M1 $=2.3 \%, \mathrm{M} 2=20.4 \%$. $(D)$ Absolute numbers of viable cells were calculated by subtracting the percentage of $\mathrm{AV}^{+}$cells in the live gate from the number of trypan blue-negative cells. Results are expressed as a percentage of the number of viable cells planted at day 0. Normal $(n=2)$ and NHL $(n=7)$ PBL-T data were identical and therefore combined (white bars). Reactive T cells, $n=9$ (gray bars). NHL-TIL, $n=3$ (black bars).

cellular event during apoptosis (30). Using forward and side scatter to gate the population of live $\mathrm{T}$ cells, we found that this gate contained $<1 \%$ of necrotic cells $\left(\mathrm{PI}^{+}\right.$cells) but a significant proportion of cells were $\mathrm{AV}^{+}$. Reactive $\mathrm{T}$ cells and NHLTIL showed greater spontaneous apoptosis than PBL-T (Fig. 3, $A-C$, shows representative examples of AV staining). Since early apoptotic cells can be $\mathrm{AV}^{+}$but can still exclude vital dyes (31), the number of surviving cells for the kinetic studies was calculated by deducting the percentage of $\mathrm{AV}^{+}$cells in the live gate by flow cytometry from the number of trypan blue-negative cells (both performed on independent but identical wells). Fig. $3 D$ shows that the cell survival kinetics of NHL-TIL was significantly poorer than PBL-T, with only $54 \%$ of planted cells still viable at day 1 and $37 \%$ at day 4 (the differences were statistically significant at day $1: P=0.025$; and day $4: P=0.0037)$. The kinetics of reactive T cell viability (53\% at day 1 and $37 \%$ at day 4) was completely superimposable with that of NHL-TIL.

Apoptosis in activated $\mathrm{T}$ cells has been correlated to cell cycle progression (32). As NHL-TIL and reactive T cells were immunophenotypically activated cells, cell cycle analysis was performed to see if the increased apoptosis was attributable to a greater proportion of cycling cells. As shown in Fig. 4, at day 0 virtually all cells were quiescent in G0/1 phase with no DNA synthesis or mitotic cells, regardless of the type of sample: $99 \%$ for normal PBL-T, 96\% for reactive T cells, and $98 \%$ for NHL-TIL (see M3 in Fig. 4, $B, D$, and $F$, respectively). After $24 \mathrm{~h}$ of culture in complete medium, cycling cells could still not be detected (Fig. 4, $H, J$, and $L$ ). However, apoptosis was more marked in NHL-TIL (Fig. $4 \mathrm{~L}, \mathrm{M} 2=37 \%$ ) and reactive T cells (Fig. $4 \mathrm{~J}, \mathrm{M} 2=44 \%$ ) than normal PBL-T (Fig. $4 \mathrm{H}, \mathrm{M} 2=$ $22 \%$ ), as shown both morphologically by the appearance of a population of smaller cells (Fig. 4: compare M1 between $A$ and $G, C$ and $I$, and $E$ and $K$ ) and in terms of a reduced DNA content, $<2$ n (Fig. 4: compare M2 between $B$ and $H, D$ and $J$, and $F$ and $L$ ), confirming the results with AV. Thus, the increased apoptosis of NHL-TIL and reactive T cells was not associated with an increased proportion of cycling cells.

Viable NHL-TIL and reactive $T$ cells modulate $B c l-2$ and $B c l-x_{L}$ expression in culture. Changes in the levels of expression of Bcl-2 and Bcl- $\mathrm{x}_{\mathrm{L}}$ have been shown to be correlated with protection from, or the induction of, apoptosis in various $\mathrm{T}$ cell populations (33). Recently, the levels of Bcl family proteins as detected by flow cytometry have been correlated with the findings on immunoprecipitation (34). Using flow cytometry to analyze the expression of these two proteins in single cells in the live gate, we found that all populations studied (NHL-TIL, reactive $\mathrm{T}$ cells, and PBL-T) gave the same profile immediately after $\mathrm{T}$ cell purification, with $100 \%$ of cells positive for both 

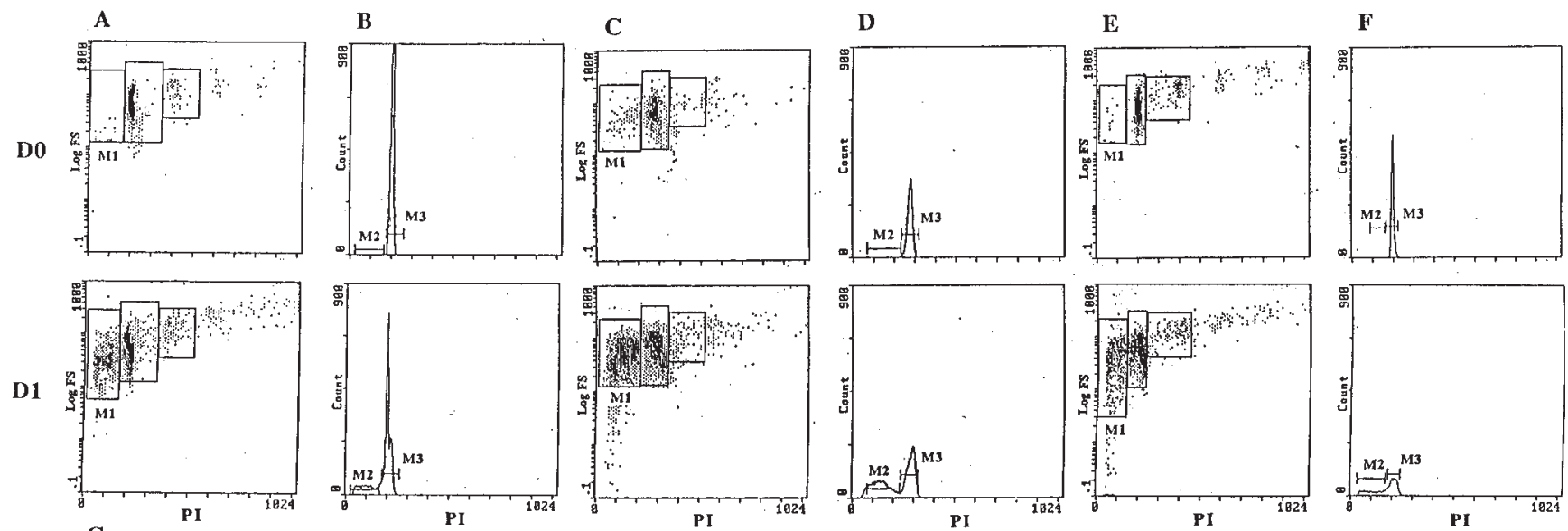

PBL-T
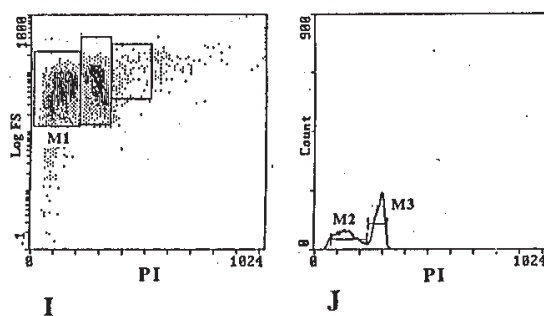

J

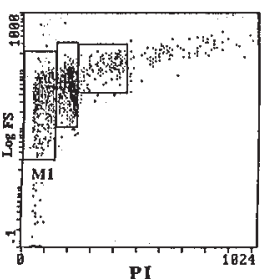

$\mathbf{K}$

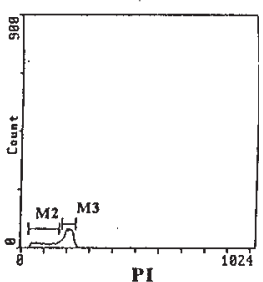

$\mathbf{L}$
Reactive T-cells

Figure 4. Cell cycle analysis: NHL-TIL are quiescent but show marked apoptosis during in vitro culture. Purified T cell populations were stained with PI for cell cycle analysis immediately after magnetic sorting $(D O)$ and after $24 \mathrm{~h}$ of culture in complete medium, without additional stimuli (D1). Morphology (size) is shown on a logarithmic scale $(\log F S)$ against PI content $(A, C, E, G, I$, and $K)$. The rectangular gates are placed as an aid to visualize the population, with M1 highlighting small, apoptotic cells. DNA content of the entire population, after exclusion of doublets, is represented by PI staining $(B, D, F, H, J$, and $L)$. The marker M2 delineates apoptotic cells (DNA content $<2 \mathrm{n})$ and M3 represents cells in G0/1 phase (DNA content $=2 \mathrm{n})$.

molecules and at a similar MFI (Fig. 5, dotted lines). After $24 \mathrm{~h}$ of culture, Bcl-2 and Bcl- $\mathrm{x}_{\mathrm{L}}$ expression in viable cells consistently showed two peaks in all populations: a major peak with a similar MFI as on day 0, and a minor peak with a lower MFI (Fig. 5). Although there were individual variations within each sample group, the $\mathrm{Bcl}-2^{\text {low }}$ and $\mathrm{Bcl}-\mathrm{x}_{\mathrm{L}}$ low peaks were most marked in NHL-TIL and reactive T cells. Outside the live gate, Bcl- $\mathrm{x}_{\mathrm{L}}$ and Bcl-2 expression was low (data not shown) and all cells were $\mathrm{AV}^{+}$. Thus, PBL-T, reactive $\mathrm{T}$ cells, and NHL-TIL all showed similar patterns of expression of Bcl-2 and Bcl- $x_{L}$ and viable cells in culture maintained Bcl-2 and Bcl- $\mathrm{x}_{\mathrm{L}}$ expression, whereas apoptotic cells had low levels of both molecules.

CD3 hyporesponsiveness of NHL-TIL and reactive $T$ cells is not directly related to apoptosis. Our results raised the question of whether the poor proliferative response of NHL-TIL and reactive $\mathrm{T}$ cells to anti-CD3 $\mathrm{mAb}$ was related to their marked in vitro apoptosis. First, we excluded the possibility that TCR/CD3 stimulation during the proliferative assays was leading to activation-induced cell death. The effect of IL-2, anti-CD3 mAb, and anti-CD3/IL-2 on NHL-TIL and reactive $\mathrm{T}$ cell survival was determined by trypan blue exclusion and AV staining (as described above). None of these conditions had any significant effect as compared with medium alone after $24 \mathrm{~h}$ of culture: $11.8,9.6,9.5$, and $8 \% \mathrm{AV}^{+}$cells and 49,48 , 53 , and $56 \%$ remaining viable cells for medium, IL-2, antiCD3, and anti-CD3/IL-2, respectively. As NHL-TIL and reactive $\mathrm{T}$ cells are Fas (CD95) positive (Table III and data not shown), the role of Fas was studied using the Fas agonist Ab, APO-1, and the blocking Ab, ZB4. ${ }^{3}$ Table III shows that while

3. To control for the ability of ZB4 to inhibit Fas-mediated apoptosis by FasL, PHA blasts were incubated with recombinant FasL, both in the presence and absence of ZB4 or an isotype control antibody. $90 \%$ of PHA blasts entered apoptosis after a 24-h incubation with FasL. The control antibody had no effect, whereas ZB4 reduced the percentage of apoptotic cells to $15 \%$. (Experiments were kindly performed by Françoise Le Deist.)

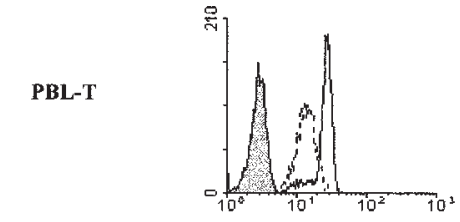

$\mathbf{A}$

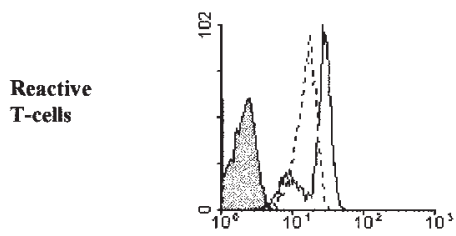

C

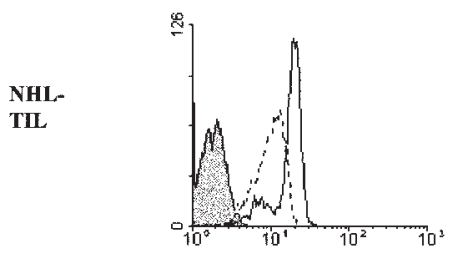

$\mathbf{E}$

$\operatorname{Bcl}-\mathbf{x}_{\mathbf{L}}$

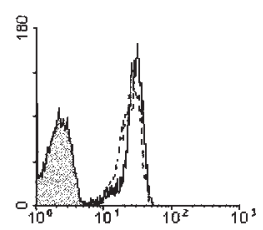

B

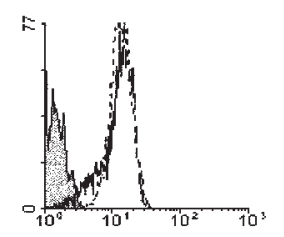

D

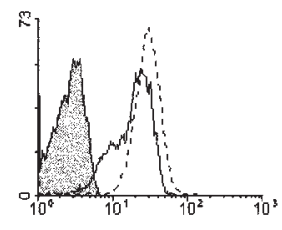

$\mathbf{F}$

Bcl-2

Figure 5. Viable $\mathrm{T}$ cells modulate expression of $\mathrm{Bcl}-\mathrm{x}_{\mathrm{L}}$ and $\mathrm{Bcl}-2$. Intracellular staining for $\mathrm{Bcl}^{-\mathrm{x}_{\mathrm{L}}}(A, C$, and $E)$ and $\operatorname{Bcl}-2(B, D$, and $F)$ was performed immediately after $\mathrm{T}$ cell purification (dotted lines) and after $24 \mathrm{~h}$ in culture in complete medium, without additional stimuli (solid lines). Forward and side scatter characteristics were used to gate the population of live T cells. Negative controls are represented by filled curves. 
Table III. T Cells from Chronic Inflammatory Lesions Are Resistant to Fas-induced Apoptosis

\begin{tabular}{|c|c|c|c|c|c|c|c|}
\hline & \multirow{3}{*}{$\begin{array}{c}\% \text { of Fas }{ }^{+} \text {cells } \\
(\mathrm{MFI})\end{array}$} & \multicolumn{6}{|c|}{ Apoptosis ( $\%$ of $\mathrm{AV}^{+} \mathrm{PI}^{-}$cells) } \\
\hline & & \multicolumn{4}{|c|}{ APO-1 (ng/ml) } & \multirow{2}{*}{$\begin{array}{c}\text { CH11 } \\
100 \mathrm{ng} / \mathrm{ml}\end{array}$} & \multirow{2}{*}{$\begin{array}{l}\text { Isotype } \\
\text { control } \\
100 \mathrm{ng} / \mathrm{ml}\end{array}$} \\
\hline & & Medium & 2.5 & 25 & 100 & & \\
\hline Reactive T cells & $100(7.1)$ & 22.7 & 17.5 & 18.5 & 19.6 & 19.1 & 15.5 \\
\hline PHA blasts & $100(49.4)$ & 6.4 & 9.7 & 21 & 26.9 & 7.5 & 9.8 \\
\hline
\end{tabular}

Fas (CD95) expression was determined with the anti-Fas mAb, CH11. For apoptosis induction, two anti-Fas mAbs were used: a Fas-activating $\mathrm{Ab}$ to induce apoptosis, APO-1, and CH11 as a control as it did not provoke apoptosis in our system. An irrelevant (IgG3) mAb was also used as an isotope control for APO-1. Cells were incubated in medium alone or with APO-1, $\mathrm{CH} 11$, or the isotype control $\mathrm{mAb}$, followed by the cross-linking Ig and cultured for 4 or $24 \mathrm{~h}$ at $37^{\circ} \mathrm{C}$. PHA blasts were used after $7 \mathrm{~d}$ of activation (i.e., $2 \mathrm{~d}$ of PHA/IL-2 followed by $5 \mathrm{~d}$ of IL-2). The results at $4 \mathrm{~h}$ shown as $\mathrm{AV}^{+} \mathrm{PI}^{-}$cells were maximal at this time point.

APO-1 induced increased apoptosis in PHA blasts, reactive T cells were completely resistant to Fas signaling by APO-1. ZB4, a blocking anti-Fas Ab, had no effect on survival kinetics (up to $4 \mathrm{~d}$ of culture). Thus, the Fas/FasL pathway does not appear to be involved in the marked spontaneous in vitro apoptosis of NHL-TIL and reactive T cells. As the vast majority of cell death occurred during the first day of culture (see Fig. 3 $D$ ), we investigated the proliferative capacity of the remaining viable $T$ cells after $24 \mathrm{~h}$ in medium alone by replanting them in wells coated with anti-CD3 mAb. Once again, no proliferation was seen (data not shown). Thus, on the one hand, the conditions used to activate NHL-TIL and reactive $\mathrm{T}$ cells do not augment apoptosis and, on the other hand, the cells resistant to apoptosis remain nonresponsive to TCR/CD3 stimulation. These results show that the nonproliferative and apoptotic phenotypes of $\mathrm{T}$ cells from malignant and nonmalignant chronic inflammatory lymphoid organs can be dissociated.

\section{Discussion}

The profound in vitro hyporesponsiveness of NHL-TIL and reactive $\mathrm{T}$ cells to $\mathrm{TCR} / \mathrm{CD} 3$ activation raises the question of their in vivo functional capacity and whether they are in an anergic state. While NHL-TIL have normal levels of the signaling molecules TCR $\zeta$, CD3 $\epsilon$, p56 ${ }^{\text {lck }}$, p599yn , and ZAP-70, which are involved in the early events after TCR/CD3 activation, p56 ${ }^{\text {lck }}$ is constitutively phosphorylated and shows low activity (22). Also, NHL-TIL do not increase the nuclear binding activity of NF- $\mathrm{B}$ and there is no induction of Rel A into the nucleus after activation by anti-CD3 mAb or IL-2 (18). Similar changes have been described in T cells in in vitro mouse models of anergy and in T cells from tumor-bearing mice $(16,17$, 35-38). Thus, based on the hyporesponsiveness to TCR/CD3 stimuli and signaling alterations described above, NHL-TIL can be regarded as anergic T cells. Given that the whole population of NHL-TIL appears to be involved and that the pattern of TCR V $\alpha$ and V $\beta$ usage of NHL-TIL is polyclonal (39), the in vivo induction of anergy is a polyclonal phenomenon, not restricted to a few antigen- or tumor-specific T cell clones. The similarity between NHL-TIL and reactive $\mathrm{T}$ cells presented in this study suggests that there are common mechanisms responsible for their state of anergy, namely, the inflammatory microenvironment. In reactive and B-NHL lymph nodes, a wide variety of cytokines has been identified (40-43). IL-10 is produced by $\mathrm{T}$ cells, monocytes/macrophages, activated $\mathrm{B}$ cells, and malignant B-NHL cells $(43,44)$. It has a direct inhibitory effect on $\mathrm{T}$ cell proliferation and IL-2 production and an indirect effect via downregulation of accessory cell function (44-47). Also, chronic activation of T cells in the presence of IL-10 promotes the development of poorly proliferative CD $4^{+}$ $\mathrm{T}$ cells which can downregulate immune responses (48). Another candidate cytokine is TGF- $\beta$, produced by lymphocytes and monocytes/macrophages. It inhibits T cell activation, cytotoxic $\mathrm{T}$ lymphocyte development, and TNF- $\alpha$ and IFN- $\gamma$ production $(49,50)$. Whereas tumor cell secretion of TGF- $\beta$ has been demonstrated in human carcinomas (51), glioblastomas (5), and Hodgkin's disease (52), little data exist on TGF- $\beta$ in B-NHL (53). In addition to soluble mediators, further complexity arises from possible interactions between NHL-TIL themselves. The strong expression of CD86 in some NHL-TIL (see Table I and inset) and their expression of cytotoxic T lymphocyte A-4 (54) provide another mechanism to downregulate the immune responses of NHL-TIL via these two molecules (55-59).

NHL-TIL and reactive T cells showed poorer in vitro survival and greater spontaneous apoptosis than PBL-T. Surprisingly, IL-2 did not prevent this spontaneous apoptosis. This may be due to the fact that these populations were not actively cycling, as the IL- $2 \mathrm{R} \gamma$ chain-common cytokines have been shown to inhibit activated $\mathrm{T}$ cell apoptosis in a variety of situations (60-62), but this is associated with increased $\mathrm{Bcl}-\mathrm{x}_{\mathrm{L}}$, Bcl-2, and cell cycling $(23,60)$. Autologous fibroblasts prevented the rapid in vitro apoptosis of $\mathrm{T}$ cells from rheumatoid synovium and this was mediated, at least in part, by integrins with the upregulation of $\mathrm{Bcl}-\mathrm{x}_{\mathrm{L}}$ but no increased cell cycling (23). These findings suggest that the in vivo survival of T cells at sites of inflammation is critically dependent on stromal factors, both cell-cell contact and soluble factors, with an important role for integrin interactions and type I interferons (23; and Pilling, D., A.N. Akbar, J. Girdlestone, N.J. Borthwick, D. Scheel-Toellner, C.D. Buckley, and M. Salmon, manuscript submitted for publication). Thus, NHL-TIL and reactive T cells, once denied the multiple signals and the anchorage of the lymph node microenvironment, are subject to anoikis (homelessness) and show an increased propensity for apoptosis in vitro, as described for adherent cells (63). Anoikis may also explain the noncycling nature of NHL-TIL and reactive T cells, as loss of anchorage-dependent signals is associated with a block of cell cycle progression in the G1 phase (64).

Our results show that the CD3 hyporesponsive and apoptotic phenotypes of NHL-TIL and reactive T cells can be dissociated. Interestingly, in a variety of models, apoptosis can be dissociated from proliferation (65), cell growth (66), and T cell anergy (67). The activated immunophenotype of NHL-TIL and reactive $\mathrm{T}$ cells and their resistance to Fas-mediated apoptosis are also features of a murine in vivo model of tolerance (68) and anergized human T cell clones (69). Induction of anergy was associated with only small increases in Bcl- $\mathrm{x}_{\mathrm{L}}, \mathrm{Bcl}-2$, and Bax expression as compared with the high levels in productively stimulated clones (69). The expression of these molecules in resting $\mathrm{T}$ cells is upregulated during activation (70). Thus, the similar levels of expression of $\mathrm{Bcl}-\mathrm{x}_{\mathrm{L}}$ and $\mathrm{Bcl}-2$ 
among NHL-TIL, reactive T cells, and normal PBL-T further support the hypothesis that NHL-TIL and reactive $\mathrm{T}$ cells have not been primed efficiently in vivo and are anergic populations.

In conclusion, our results demonstrate that NHL-TIL and $\mathrm{T}$ cells from chronic inflammatory, nonmalignant conditions show hyporesponsiveness to TCR/CD3 activation and poor in vitro survival kinetics, with similar modulation of the antiapoptotic molecules $\mathrm{Bcl}-2$ and $\mathrm{Bcl}-\mathrm{x}_{\mathrm{L}}$. Thus, the quiescent, nonproliferating, anergic phenotype of NHL-TIL cannot be attributed solely to tumor-related factors, rather there are factors common to inflammatory microenvironments leading to downregulation of the recruited $\mathrm{T}$ cells in an antigen-independent manner. Therapeutic strategies in B-NHL based on manipulation of the immune system must take into account the phenomena of anergy and spontaneous in vitro apoptosis described here.

\section{Acknowledgments}

We thank Catharine Balmale for her assistance with statistical analysis.

This work was supported by grants from ARC (Cancer Research Association, no. 9253), the Conseil Régional de l'Ile de France, and the Fondation de France (project no., 97001161).

\section{References}

1. Cardoso, A.A., J.L. Schultze, V.A. Boussiotis, G.J. Freeman, M.J. Seamon, S. Laszlo, A. Billet, S.E. Sallan, J.G. Gribben, and L.M. Nadler. 1996. Pre-B acute lymphoblastic leukemia cells may induce T-cell anergy to alloantigen. Blood. 88:41-48.

2. Gajewski, T.F., F. Fallarino, C. Uyttenhove, and T. Boon. 1996. Tumor rejection requires a CTLA4 ligand provided by the host or expressed on the tumor: superiority of B7-1 over B7-2 for active tumor immunization. J. Immunol. 156:2909-2917.

3. Gajewski, T.F. 1996. B7-1 but not B7-2 efficiently costimulates CD8+ T lymphocytes in the P815 tumor system in vitro. J. Immunol. 156:465-472.

4. Hersh, E.M., and B. Drewinko. 1974. Specific inhibition of lymphocyte blastogenic responses to mitogens by a factor produced by cultured human malignant lymphoma cells. Cancer Res. 34:215-220.

5. Roszman, T., L. Elliott, and W. Brooks. 1991. Modulation of T-cell function by gliomas. Immunol. Today. 12:370-374.

6. Miescher, S., T.L. Whiteside, S. Carrel, and V. von Fliedner. 1986. Functional properties of tumor-infiltrating and blood lymphocytes in patients with solid tumors: effects of tumor cells and their supernatants on proliferative responses of lymphocytes. J. Immunol. 136:1899-1907.

7. Miescher, S., T.L. Whiteside, L. Moretta, and V. von Fliedner. 1987. Clonal and frequency analyses of tumor-infiltrating $\mathrm{T}$ lymphocytes from human solid tumors. J. Immunol. 138:4004-4011.

8. Miescher, S., M. Stoeck, L. Qiao, C. Barras, L. Barrelet, and V. von Fliedner. 1988. Proliferative and cytolytic potentials of purified human tumorinfiltrating $\mathrm{T}$ lymphocytes. Impaired response to mitogen-driven stimulation despite T-cell receptor expression. Int. J. Cancer. 42:659-666.

9. Finke, J.H., A.H. Zea, J. Stanley, D.L. Longo, H. Mizoguchi, R.R. Tubbs, R.H. Wiltrout, J.J. O'Shea, S. Kudoh, E. Klein, et al. 1993. Loss of T-cell receptor zeta chain and p56lck in T-cells infiltrating human renal cell carcinoma. Cancer Res. 53:5613-5616.

10. Alexander, J.P., S. Kudoh, K.A. Melsop, T.A. Hamilton, M.G. Edinger, R.R. Tubbs, D. Sica, L. Tuason, E. Klein, R.M. Bukowski, et al. 1993. T-cells infiltrating renal cell carcinoma display a poor proliferative response even though they can produce interleukin 2 and express interleukin 2 receptors. Cancer Res. 53:1380-1387.

11. Kudoh, S., Q. Wang, O.F. Hidalgo, P. Rayman, R.R. Tubbs, M.G. Edinger, V. Kolenko, J. Panuto, R. Bukowski, and J.H. Finke. 1995. Responses to $\mathrm{T}$ cell receptor/CD3 and interleukin-2 receptor stimulation are altered in $\mathrm{T}$ cells from B cell non-Hodgkin's lymphomas. Cancer Immunol. Immunother. 41: 175-184.

12. Jacob, M.C., M.P. Piccinni, T. Bonnefoix, M.F. Sotto, P. Couderc, J.C. Bensa, and J.J. Sotto. 1990. T lymphocytes from invaded lymph nodes in patients with B-cell-derived non-Hodgkin's lymphoma: reactivity toward the malignant clone. Blood. 75:1154-1162.

13. Boirivant, M., R. Pica, R. DeMaria, R. Testi, F. Pallone, and W. Strober. 1996. Stimulated human lamina propria T cells manifest enhanced Fas-mediated apoptosis. J. Clin. Invest. 98:2616-2622.
14. Maurice, M.M., A.C. Lankester, A.C. Bezemer, M.F. Geertsma, P.P. Tak, F.C. Breedveld, R.A. van Lier, and C.L. Verweij. 1997. Defective TCRmediated signaling in synovial $\mathrm{T}$ cells in rheumatoid arthritis. J. Immunol. 159: 2973-2978.

15. Pirzer, U.C., G. Schurmann, S. Post, M. Betzler, and S.C. Meuer. 1990. Differential responsiveness to CD3-Ti vs. CD2-dependent activation of human intestinal T lymphocytes. Eur. J. Immunol. 20:2339-2342.

16. Mizoguchi, H., J.J. O’Shea, D.L. Longo, C.M. Loeffler, D.W. McVicar, and A.C. Ochoa. 1992. Alterations in signal transduction molecules in T lymphocytes from tumor-bearing mice. Science. 258:1795-1798.

17. Franco, J.L., P. Ghosh, R.H. Wiltrout, C.R. Carter, A.H. Zea, N. Momozaki, A.C. Ochoa, D.L. Longo, T.J. Sayers, and K.L. Komschlies. 1995. Partial degradation of T-cell signal transduction molecules by contaminating granulocytes during protein extraction of splenic $\mathrm{T}$ cells from tumor-bearing mice. Cancer Res. 55:3840-3846.

18. Li, X., J. Liu, J.K. Park, T.A. Hamilton, P. Rayman, E. Klein, M. Edinger, R. Tubbs, R. Bukowski, and J. Finke. 1994. T cells from renal cell carcinoma patients exhibit an abnormal pattern of kappa B-specific DNA-binding activity: a preliminary report. Cancer Res. 54:5424-5429.

19. Levey, D.L., and P.K. Srivastava. 1996. Alterations in T cells of cancerbearers: whence specificity? Immunol. Today. 17:365-368.

20. Nakagomi, H., M. Petersson, I. Magnusson, C. Juhlin, M. Matsuda, H. Mellstedt, J.L. Taupin, E. Vivier, P. Anderson, and R. Kiessling. 1993. Decreased expression of the signal-transducing zeta chains in tumor-infiltrating T-cells and NK cells of patients with colorectal carcinoma. Cancer Res. 53:5610-5612.

21. Cardi, G., J.A. Heaney, A.R. Schned, D.M. Phillips, M.T. Branda, and M.S. Ernstoff. 1997. T-cell receptor zeta-chain expression on tumor-infiltrating lymphocytes from renal cell carcinoma. Cancer Res. 57:3517-3519.

22. Wang, Q., J. Stanley, S. Kudoh, J. Myles, V. Kolenko, T. Yi, R. Tubbs, R. Bukowski, and J. Finke. 1995. T cells infiltrating non-Hodgkin's B cell lymphomas show altered tyrosine phosphorylation pattern even though $\mathrm{T}$ cell receptor/CD3-associated kinases are present. J. Immunol. 155:1382-1392.

23. Salmon, M., D. Scheel-Toellner, A.P. Huissoon, D. Pilling, N. Shamsadeen, H. Hyde, A.D. D'Angeac, P.A. Bacon, P. Emery, and A.N. Akbar. 1997. Inhibition of T cell apoptosis in the rheumatoid synovium. J. Clin. Invest. 99:439-446.

24. Rieux-Laucat, F., F. Le Deist, C. Hivroz, I.A. Roberts, K.M. Debatin, A. Fischer, and J.P. de Villartay. 1995. Mutations in Fas associated with human lymphoproliferative syndrome and autoimmunity. Science. 268:1347-1349.

25. Hathcock, K.S., G. Laszlo, C. Pucillo, P. Linsley, and R.J. Hodes. 1994 Comparative analysis of B7-1 and B7-2 costimulatory ligands: expression and function. J. Exp. Med. 180:631-640.

26. Boussiotis, V.A. G.J. Freeman, J.G. Gribben, J. Daley, G. Gray, and L.M. Nadler. 1993. Activated human B lymphocytes express three CTLA-4 counterreceptors that costimulate T-cell activation. Proc. Natl. Acad. Sci. USA. 90:11059-11063.

27. Schiavon, V., P. Roth, W.E. Bolton, J.P. Farcet, A. Bensussan, and L. Boumsell. 1996. Lymphocyte subsets in normal individuals: analysis by four color immunofluorescence and flow cytometry on whole blood. Tissue Antigens. 48:312-318.

28. Byrne, J.A., J.L. Butler, and M.D. Cooper. 1988. Differential activation requirements for virgin and memory T cells. J. Immunol. 141:3249-3257.

29. Horgan, K.J., G.A. Van Seventer, Y. Shimizu, and S. Shaw. 1990. Hyporesponsiveness of "naive" $(\mathrm{CD} 45 \mathrm{RA}+)$ human $\mathrm{T}$ cells to multiple receptormediated stimuli but augmentation of responses by co-stimuli. Eur. J. Immunol. 20:1111-1118

30. Koopman, G., C.P. Reutelingsperger, G.A. Kuijten, R.M. Keehnen, S.T. Pals, and M.H. van Oers. 1994. Annexin V for flow cytometric detection of phosphatidylserine expression on B cells undergoing apoptosis. Blood. 84: $1415-1420$.

31. Naito, M., K. Nagashima, T. Mashima, and T. Tsuruo. 1997. Phosphatidylserine externalization is a downstream event of interleukin-1 $\beta$-converting enzyme family protease activation during apoptosis. Blood. 89:2060-2066.

32. Boehme, S.A., and M.J. Lenardo. 1993. Propriocidal apoptosis of mature $\mathrm{T}$ lymphocytes occurs at $\mathrm{S}$ phase of the cell cycle. Eur. J. Immunol. 23 . 1552-1560.

33. Chao, D.T., and S.J. Korsmeyer. 1998. BCL-2 family: regulators of cell death. Annu. Rev. Immunol. 16:395-419.

34. Akbar, A.N., N.J. Borthwick, R.G. Wickremasinghe, P. Panayoitidis, D. Pilling, M. Bofill, S. Krajewski, J.C. Reed, and M. Salmon. 1996. Interleukin-2 receptor common gamma-chain signaling cytokines regulate activated $\mathrm{T}$ cell apoptosis in response to growth factor withdrawal: selective induction of antiapoptotic (bcl-2, bcl-xL) but not pro-apoptotic (bax, bcl-xS) gene expression. Eur. J. Immunol. 26:294-299.

35. Cho, E.A., M.P. Riley, A.L. Sillman, and H. Quill. 1993. Altered protein tyrosine phosphorylation in anergic Th1 cells. J. Immunol. 151:20-28.

36. Correa, M.R., A.C. Ochoa, P. Ghosh, H. Mizoguchi, L. Harvey, and D.L. Longo. 1997. Sequential development of structural and functional alterations in T cells from tumor-bearing mice. J. Immunol. 158:5292-5296.

37. Migita, K., K. Eguchi, Y. Kawabe, T. Tsukada, Y. Ichinose, S. Nagataki, and A. Ochi. 1995. Defective TCR-mediated signaling in anergic T cells. J. Immunol. 155:5083-5087.

38. Loeffler, C.M., M.J. Smyth, D.L. Longo, W.C. Kopp, L.K. Harvey, H.R. 
Tribble, J.E. Tase, W.J. Urba, A.S. Leonard, H.A. Young, et al. 1992. Immunoregulation in cancer-bearing hosts. Down-regulation of gene expression and cytotoxic function in CD8+ T cells. J. Immunol. 149:949-956.

39. Xerri, L., M.P. Mathoulin, F. Birg, R. Bouabdallah, A.M. Stoppa, and J. Hassoun. 1994. Heterogeneity of rearranged T-cell receptor V-alpha and V-beta transcripts in tumor-infiltrating lymphocytes from Hodgkin's disease and non-Hodgkin's lymphoma. Am. J. Clin. Pathol. 101:76-80.

40. Hsu, S.M., J.W. Waldron, Jr., P.L. Hsu, and A.J. Hough, Jr. 1993. Cytokines in malignant lymphomas: review and prospective evaluation. Hum. Pathol. 24:1040-1057.

41. Peuchmaur, M., D. Emilie, M.C. Crevon, N. Brousse, P. Gaulard, M.F. D'Agay, P. Galanaud, and P. Solal-Celigny. 1991. Interleukin-2 and interferongamma production in follicular lymphomas. Am. J. Clin. Pathol. 95:55-62.

42. Toellner, K.M., D. Scheel-Toellner, R. Sprenger, M. Duchrow, L.H. Trumper, M. Ernst, H.D. Flad, and J. Gerdes. 1995. The human germinal centre cells, follicular dendritic cells and germinal centre T cells produce B cell-stimulating cytokines. Cytokine. 7:344-354.

43. Voorzanger, N., R. Touitou, E. Garcia, H.J. Delecluse, F. Rousset, I. Joab, M.C. Favrot, and J.Y. Blay. 1996. Interleukin (IL)-10 and IL-6 are produced in vivo by non-Hodgkin's lymphoma cells and act as cooperative growth factors. Cancer Res. 56:5499-5505.

44. Moore, K.W., A. O'Garra, R. de Waal Malefyt, P. Vieira, and T.R. Mosmann. 1993. Interleukin-10. Annu. Rev. Immunol. 11:165-190.

45. de Waal Malefyt, R., H. Yssel, and J.E. de Vries. 1993. Direct effects of IL-10 on subsets of human CD4+ T cell clones and resting T cells. Specific inhibition of IL-2 production and proliferation. J. Immunol. 150:4754-4765.

46. Del Prete, G., M. De Carli, F. Almerigogna, M.G. Giudizi, R. Biagiotti, and S. Romagnani. 1993. Human IL-10 is produced by both type 1 helper (Th1) and type 2 helper (Th2) T cell clones and inhibits their antigen-specific proliferation and cytokine production. J. Immunol. 150:353-360.

47. Taga, K., H. Mostowski, and G. Tosato. 1993. Human interleukin-10 can directly inhibit T-cell growth. Blood. 81:2964-2971.

48. Groux, H., A. O'Garra, M. Bigler, M. Rouleau, S. Antonenko, J.E. de Vries, and M.G. Roncarolo. 1997. A CD4+ T-cell subset inhibits antigen-specific T-cell responses and prevents colitis. Nature. 389:737-742.

49. Ranges, G.E., I.S. Figari, T. Espevik, and M.A. Palladino, Jr. 1987. Inhibition of cytotoxic $\mathrm{T}$ cell development by transforming growth factor beta and reversal by recombinant tumor necrosis factor alpha. J. Exp. Med. 166:991-998.

50. Tada, T., S. Ohzeki, K. Utsumi, H. Takiuchi, M. Muramatsu, X.F. Li, J. Shimizu, H. Fujiwara, and T. Hamaoka. 1991. Transforming growth factorbeta-induced inhibition of $\mathrm{T}$ cell function. Susceptibility difference in $\mathrm{T}$ cells of various phenotypes and functions and its relevance to immunosuppression in the tumor-bearing state. J. Immunol. 146:1077-1082.

51. Vanky, F., N. Nagy, C. Hising, K. Sjovall, B. Larson, and E. Klein. 1997. Human ex vivo carcinoma cells produce transforming growth factor beta and thereby can inhibit lymphocyte functions in vitro. Cancer Immunol. Immunother. 43:317-323.

52. Kadin, M.E., B.A. Agnarsson, L.R. Ellingsworth, and S.R. Newcom. 1990. Immunohistochemical evidence of a role for transforming growth factor beta in the pathogenesis of nodular sclerosing Hodgkin's disease. Am. J. Pathol. 136:1209-1214.

53. Newcom, S.R., K.K. Tagra, and M.E. Kadin. 1992. Neutralizing antibodies against transforming growth factor beta potentiate the proliferation of Ki-1 positive lymphoma cells. Further evidence for negative autocrine regulation by transforming growth factor beta. Am. J. Pathol. 140:709-718.

54. Xerri, L., E. Devilard, J. Hassoun, D. Olive, and F. Birg. 1997. In vivo expression of the CTLA4 inhibitory receptor in malignant and reactive cells from human lymphomas. J. Pathol. 183:182-187.
55. Blair, P.L., J.L. Riley, B.L. Levine, K.P. Lee, N. Craighead, T. Francomano, S.J. Perfetto, G.S. Gray, B.M. Carreno, and C.H. June. 1998. CTLA-4 ligation delivers a unique signal to resting human $\mathrm{CD} 4 \mathrm{~T}$ cells that inhibits interleukin-2 secretion but allows Bcl-XL induction. J. Immunol. 160:12-15.

56. Gribben, J.G., G.J. Freeman, V.A. Boussiotis, P. Rennert, C.L. Jellis, E. Greenfield, M. Barber, V.A. Restivo, Jr., X. Ke, G.S. Gray, et al. 1995. CTLA4 mediates antigen-specific apoptosis of human T cells. Proc. Natl. Acad. Sci. USA. 92:811-815.

57. Hollsberg, P., C. Scholz, D.E. Anderson, E.A. Greenfield, V.K. Kuchroo, G.J. Freeman, and D.A. Hafler. 1997. Expression of a hypoglycosylated form of CD86 (B7-2) on human T cells with altered binding properties to CD28 and CTLA-4. J. Immunol. 159:4799-4805.

58. Krummel, M.F., and J.P. Allison. 1995. CD28 and CTLA-4 have opposing effects on the response of T cells to stimulation. J. Exp. Med. 182:459-465.

59. Krummel, M.F., and J.P. Allison. 1996. CTLA-4 engagement inhibits IL-2 accumulation and cell cycle progression upon activation of resting $\mathrm{T}$ cells. J. Exp. Med. 183:2533-2540.

60. Akbar, A.N., N. Borthwick, M. Salmon, W. Gombert, M. Bofill, N. Shamsadeen, D. Pilling, S. Pett, J.E. Grundy, and G. Janossy. 1993. The significance of low bcl-2 expression by CD45RO T cells in normal individuals and patients with acute viral infections. The role of apoptosis in T cell memory. J. Exp. Med. 178:427-438.

61. Estaquier, J., M. Tanaka, T. Suda, S. Nagata, P. Golstein, and J.C. Ameisen. 1996. Fas-mediated apoptosis of CD4+ and CD8+ T cells from human immunodeficiency virus-infected persons: differential in vitro preventive effect of cytokines and protease antagonists. Blood. 87:4959-4966.

62. Groux, H., D. Monte, B. Plouvier, A. Capron, and J.C. Ameisen. 1993 CD3-mediated apoptosis of human medullary thymocytes and activated peripheral T cells: respective roles of interleukin-1, interleukin-2, interferon-gamma and accessory cells. Eur. J. Immunol. 23:1623-1629.

63. Frisch, S.M., and H. Francis. 1994. Disruption of epithelial cell-matrix interactions induces apoptosis. J. Cell Biol. 124:619-626.

64. Guadagno, T.M., M. Ohtsubo, J.M. Roberts, and R.K. Assoian. 1993. A link between cyclin A expression and adhesion-dependent cell cycle progression. Science. 262:1572-1575.

65. Nunez, G., L. London, D. Hockenbery, M. Alexander, J.P. McKearn, and S.J. Korsmeyer. 1990. Deregulated Bcl-2 gene expression selectively prolongs survival of growth factor-deprived hemopoietic cell lines. J. Immunol. 144:3602-3610.

66. Deckwerth, T.L., J.L. Elliott, C.M. Knudson, E.M. Johnson, Jr., W.D. Snider, and S.J. Korsmeyer. 1996. BAX is required for neuronal death after trophic factor deprivation and during development. Neuron. 17:401-411.

67. Hargreaves, R.G., N.J. Borthwick, M.S. Montani, E. Piccolella, P. Carmichael, R.I. Lechler, A.N. Akbar, and G. Lombardi. 1997. Dissociation of T cell anergy from apoptosis by blockade of Fas/Apo-1 (CD95) signaling. J. Immunol. 158:3099-3107.

68. Perez, V.L., L. Van Parijs, A. Biuckians, X.X. Zheng, T.B. Strom, and A.K. Abbas. 1997. Induction of peripheral T cell tolerance in vivo requires CTLA-4 engagement. Immunity. 6:411-417.

69. Boussiotis, V.A., B.J. Lee, G.J. Freeman, J.G. Gribben, and L.M. Nadler. 1997. Induction of T cell clonal anergy results in resistance, whereas CD28-mediated costimulation primes for susceptibility to Fas- and Bax-mediated programmed cell death. J. Immunol. 159:3156-3167.

70. Broome, H.E., C.M. Dargan, S. Krajewski, and J.C. Reed. 1995. Expression of Bcl-2, Bcl-x, and Bax after T cell activation and IL-2 withdrawal. J. Immunol. 155:2311-2317.

71. Behrens, T.W., and D.L. Mueller. 1997. Bcl-x and the regulation of survival in the immune system. Immunol. Res. 16:149-160. 